\title{
Presurgical Pazopanib Improves Surgical Outcomes for Renal Cell Carcinoma With High-level IVC Tumor Thrombosis
}

\author{
YASUYOSHI OKAMURA, TOMOAKI TERAKAWA, MARIKO SAKAMOTO, \\ YUKARI BANDO, KOTARO SUZUKI, TAKUTO HARA, JUNYA FURUKAWA, \\ KENICHI HARADA, NOBUYUKI HINATA, YUZO NAKANO and MASATO FUJISAWA \\ Department of Urology, Kobe University Graduate School of Medicine, Kobe, Japan
}

\begin{abstract}
Background/ Aim: We evaluated surgical outcomes following nephrectomy and thrombectomy with and without presurgical treatment with pazopanib in patients with advanced renal cell carcinoma with inferior vena caval tumor thrombosis. Materials and Methods: We compared surgical outcomes between patients undergoing presurgical treatment with pazopanib vs. surgery-alone in 19 patients who underwent surgery for advanced renal cell carcinoma with high-level inferior vena caval tumor thrombosis at the Kobe University Hospital. Results: Comparing the presurgical group with the surgery-alone group, respectively, the average operative time was 497 min vs. $627 \min (p=0.08)$; average blood loss was 1,928 ml vs. 7,393 $\mathrm{ml}(p<0.05)$; average postoperative hospitalization duration was 15.3 days vs. 21.6 days ( $p=0.05)$; and the perioperative complication rate was lower (presurgical: $33 \%$ vs. surgery-alone: $50 \%$ ). Conclusion: Presurgical treatment with pazopanib decreased surgical difficulty and improved surgical outcomes for advanced renal cell carcinoma with high-level inferior vena caval tumor thrombosis.
\end{abstract}

Renal cell carcinoma (RCC) has the unique clinical feature of extension into the venous system. Ten percent of patients with RCC present with an intravenous tumor thrombus invading the renal vein or inferior vena cava (IVC), and $1 \%$ present with a tumor thrombus extending into the right atrium (1). The Mayo classification system is widely used to determine the tumor thrombus level. Surgical approaches

This article is freely accessible online.

Correspondence to: Tomoaki Terakawa, MD, Ph.D., Department of Urology, Kobe University Graduate School of Medicine, 7-5-1, Kusunoki-cho, Kobe 6500017, Japan. Tel: +81 783826155, Fax: +81783826169, e-mail: daatera0804@yahoo.co.jp

Key Words: Inferior vena cava, molecular-targeted therapy, renal cell carcinoma, presurgical therapy, thrombosis. vary depending on the level of the tumor thrombus (1), with surgical procedures becoming more difficult and perioperative complication rates increasing with higher tumor thrombus levels (2). In particular, level III and IV thrombi require invasive procedures such as hepatic mobilization, a thoracic cavity approach, and extracorporeal circulation.

Several studies have reported the efficacy of presurgical treatment with molecular-targeted drugs for locallyadvanced, metastatic RCC (3-10), and for tumor thrombi extending into the IVC (11-15). Reducing the tumor thrombus level decreases both surgical difficulty and intraoperative blood loss as a result of improved venous return status owing to the vena cava thrombus.

Several studies have suggested a limited efficacy with presurgical treatment for IVC tumor thrombosis regarding decreased tumor size and tumor thrombosis (13-15). However, pazopanib is a molecular-targeted drug approved worldwide for the treatment of advanced RCC $(16,17)$. Pazopanib has been shown to be non-inferior to sunitinib regarding progression-free survival and safety, and quality of life profiles and objective response rates were better with pazopanib than with sunitinib (18). Early tumor shrinkage by pazopanib has been reported compared to other tyrosine kinase inhibitors (19); therefore, we considered that pazopanib was optimal for presurgical treatment in RCC patients with IVC tumor thrombosis.

The objective of this study was to evaluate surgical outcomes following resection of both tumor and thrombus by comparing presurgical treatment with pazopanib for RCC patients with level III or IV thrombus vs. surgery-alone.

\section{Patients and Methods}

This study was approved by the institutional review board of Kobe University Hospital (approval No.170073). Informed consent for the treatment and evaluation was obtained from all the patients. We performed a retrospective chart review of 16 patients who underwent surgery for advanced RCC with level III or IV IVC tumor thrombosis at Kobe University Hospital from March 2008 to 
September 2018. Baseline assessments included patients' background characteristics, laboratory data, treatment history, clinical stage of RCC, tumor thrombus level, and prognostic profiles. Presurgical treatment was started after 2016. The presurgical group included patients with III or IV IVC tumor thrombosis who consented to receive presurgical treatment after 2016. We used pazopanib for presurgical treatment and the MAYO classification system to determine the tumor thrombus level. Most commonly, presurgical treatment involved 12 weeks of $800 \mathrm{mg}$ of oral pazopanib until 1 week before surgery. We evaluated the surgical outcomes of patients who received presurgical treatment compared with those undergoing surgery alone and recorded intraoperative blood loss volume, operative time, surgical procedure, and complication rates for each group. Patient treatment responses were generally evaluated every 4 weeks from the start of treatment using chest and abdominopelvic computed tomography. Each patient's response and adverse events were evaluated by the treating physician using the Response Evaluation Criteria in Solid Tumors 1.0 and National Cancer Institute Common Terminology Criteria for Adverse Events version 3.0. Perioperative complications were evaluated by the Clavien-Dindo surgical complications classification system.

Statistical analysis. Categorical variables were compared using Fisher's exact test. Quantitative variables were expressed as means with standard deviation. Differences between the groups were compared using the t test. All statistical analyses were performed using R for Windows v3.4.4 software (www.r-project.org). Probability $(p)$ values $<0.05$ were considered significant.

\section{Results}

Patients' background characteristics are shown in Table I. Nine patients received presurgical treatment, and the remaining 10 patients underwent surgery alone. There were no significant differences in patients' characteristics between the groups.

The findings in the presurgical treatment group are shown Table II. All patients in the presurgical group showed obvious shrinkage of the primary tumor and thrombus to some extent, and seven patients gained a lower tumor thrombus level. Among these seven patients, four patients avoided a thoracic cavity approach and extracorporeal circulation, and the remaining three patients avoided hepatic mobilization and hepatic vein clamping. Tumor responses to presurgical treatment included a partial response in four patients and stable disease in five patients.

As shown in Figure 1, when comparing the presurgical group with the surgery-alone group, the average operative time was $497 \min v s .628 \mathrm{~min}(p=0.08)$; the average blood loss volume (Figure 2) was $1928 \mathrm{ml} \mathrm{vs.} 7393 \mathrm{ml}(p=0.03)$; and the average postoperative hospitalization duration (Figure 3) was 15.3 days vs. 21.6 days $(p=0.05)$.

Table III shows patients' perioperative complications, which occurred in $50 \%$ of patients in the surgery-alone group and $33 \%$ in the presurgical group. One surgery-related death occurred in the surgery-alone group; the patient died two
Table I. Patient characteristics.

\begin{tabular}{|c|c|c|c|}
\hline & $\begin{array}{l}\text { Surgery alone } \\
\qquad(\mathrm{N}=10)\end{array}$ & $\begin{array}{l}\text { Presurgical } \\
\quad(N=9)\end{array}$ & \\
\hline $\begin{array}{l}\text { Age, years } \\
\text { average, range }\end{array}$ & $69.8(44-83)$ & $71.4(53-79)$ & $p=0.75$ \\
\hline \multicolumn{4}{|l|}{ Gender } \\
\hline Male & $9(90)$ & $5(66)$ & \\
\hline Female & $1(10)$ & $4(33)$ & $p=0.14$ \\
\hline \multicolumn{4}{|l|}{ ECOG PS } \\
\hline 0 & $6(60)$ & $5(56)$ & \\
\hline 1 & $4(40)$ & $3(33)$ & \\
\hline$>1$ & $0(0)$ & $1(11)$ & $p=1.00$ \\
\hline \multicolumn{4}{|l|}{ Laterality } \\
\hline Left & $1(10)$ & $0(0)$ & \\
\hline Right & $9(90)$ & $9(100)$ & $p=1.00$ \\
\hline \multicolumn{4}{|c|}{ Level of tumor thrombus } \\
\hline III & $5(50)$ & $4(44)$ & \\
\hline IV & $5(50)$ & $5(56)$ & $p=1.00$ \\
\hline \multicolumn{4}{|l|}{ Clinical $\mathrm{T}$ stage } \\
\hline $3 b$ & $5(50)$ & $5(56)$ & \\
\hline $3 c$ & $5(50)$ & $4(44)$ & $p=1.00$ \\
\hline \multicolumn{4}{|l|}{ Clinical N stage } \\
\hline 0 & $8(80)$ & $3(83)$ & \\
\hline 1 & $1(10)$ & $0(0)$ & \\
\hline 2 & $1(10)$ & $1(17)$ & $p=1.00$ \\
\hline \multicolumn{4}{|l|}{ Clinical M stage } \\
\hline 0 & $7(70)$ & $3(33)$ & \\
\hline 1 & $3(30)$ & $6(66)$ & $p=0.18$ \\
\hline \multicolumn{4}{|l|}{ Histological type } \\
\hline Clear cell & $9(90)$ & $8(83)$ & \\
\hline Other & $1(10)$ & $1(17)$ & $p=1.00$ \\
\hline
\end{tabular}

ECOG PS: Eastern Cooperative Oncology Group performance status.

months after surgery secondary to multiple organ failure. Higher than grade 3 perioperative complications occurred in two surgery-alone group of patients: one patient with pneumothorax and another with pancreatitis. Adverse events related to pazopanib are shown in Table IV. Eight patients presented at least one adverse event. Higher than grade 3 adverse events occurred in three patients (thrombocytopenia, Hand foot syndrome).

\section{Discussion}

We evaluated surgical outcomes following nephrectomy and thrombectomy by comparing patients receiving presurgical treatment with pazopanib vs. surgery-alone in patients with RCC and level III or IV IVC tumor thrombosis. A significantly lower intraoperative blood loss volume and postoperative hospitalization duration without longer operative times were obtained in the presurgical treatment group.

Surgical treatment for RCC with IVC thrombosis is a standard option. Although previous studies have shown that 
Table II. Details of the presurgical treatment group.

\begin{tabular}{|c|c|c|c|c|c|c|c|c|c|c|}
\hline Patient & Gender & Age & $\begin{array}{l}\text { Histology of } \\
\text { nephrectomy } \\
\text { specimen }\end{array}$ & $\begin{array}{l}\text { Clinical } \\
\text { stage }\end{array}$ & $\begin{array}{l}\text { Response } \\
\text { at } 3 \\
\text { months }\end{array}$ & $\begin{array}{c}\text { Response of } \\
\text { thrombus } \\
\text { level }\end{array}$ & $\begin{array}{c}\text { Response on } \\
\text { thrombus } \\
\text { diameter }(\mathrm{mm} . \%)\end{array}$ & $\begin{array}{l}\text { Response on } \\
\text { thrombus } \\
\text { length }(\mathrm{mm}, \%)\end{array}$ & $\begin{array}{l}\text { Operative } \\
\text { time }(\mathrm{min})\end{array}$ & $\begin{array}{l}\text { Blood loss } \\
\text { volume } \\
\quad(\mathrm{ml})\end{array}$ \\
\hline 1 & Male & 66 & Clear cell & cT3cN0M1 & PR & $4 \rightarrow 2$ & $-9(18)$ & $-45(32)$ & 593 & 3660 \\
\hline 2 & Female & 69 & Clear cell & $\mathrm{cT} 3 \mathrm{cN} 0 \mathrm{M} 1$ & PR & $4 \rightarrow 1$ & $-9(38)$ & $-58(63)$ & 294 & 510 \\
\hline 3 & Female & 53 & $\begin{array}{l}\text { Clear cell with } \\
\text { sarcomatoid } \\
\text { differentiation }\end{array}$ & cT3bN2M1 & SD & $3 \rightarrow 2$ & $-4(15)$ & $-9(13)$ & 370 & 950 \\
\hline 4 & Male & 79 & $\begin{array}{c}\text { Unknown } \\
\text { (total necrosis) }\end{array}$ & $\mathrm{cT} 3 \mathrm{cN} 0 \mathrm{M} 0$ & SD & $4 \rightarrow 4$ & $-12(24)$ & $-25(18)$ & 674 & 2210 \\
\hline 5 & Male & 69 & Clear cell & cT3bNOM0 & SD & $3 \rightarrow 3$ & $-7(18)$ & $-12(14)$ & 636 & 1674 \\
\hline 6 & Male & 79 & Clear cell & cT3bN0M1 & SD & $3 \rightarrow 2$ & $-14(33)$ & $-18(26)$ & 436 & 600 \\
\hline 7 & Female & 81 & Clear cell & cT3bN0M0 & SD & $3 \rightarrow 2$ & $-10(38)$ & $-47(46)$ & 420 & 550 \\
\hline 8 & Female & 67 & Clear cell & $\mathrm{cT} 3 \mathrm{cN} 0 \mathrm{M} 1$ & PR & $4 \rightarrow 3$ & $-29(67)$ & $-39(29)$ & 729 & 6945 \\
\hline 9 & Male & 80 & Clear cell & cT3bN0M1 & PR & $4 \rightarrow 2$ & $-7(25)$ & $-58(61)$ & 328 & 250 \\
\hline
\end{tabular}

PR: Partial response; SD: stable disease.

Table III. Perioperative complications.

\begin{tabular}{lcccc}
\hline & \multicolumn{2}{c}{ Surgery alone $(\mathrm{N}=10)$} & \multicolumn{2}{c}{ Presurgical $(\mathrm{N}=9)$} \\
\cline { 2 - 5 } & All grade & Grade $>3$ & All grade & Grade $>3$ \\
\hline Ileus & 3 & & 1 & \\
Pancreatitis & 1 & 1 & & \\
Pneumothorax & 1 & 1 & 1 & \\
Tachycardia & 1 & & 1 \\
Wound infections & & & 1 \\
Vein thrombus & & &
\end{tabular}

$29 \%-55 \%$ of patients with tumor thrombosis have distant metastasis, surgical treatment can provide long-term survival for patients with RCC with tumor thrombosis without metastasis (2); however, this surgery is one of the most challenging urological surgeries. Mortality rates with surgery range from $2.7 \%-13 \%$, which is high compared with mortality rates for other surgeries $(20,21)$, and surgical difficulty and perioperative complication rates increase with higher tumor thrombus levels. Recently, neoadjuvant treatment for advanced or metastatic RCC has been reported in several studies (7-14), and another study expanded neoadjuvant therapy for localized RCC, for nephron-sparing (22). Reducing tumor thrombus size can decrease surgical difficulty and increase safety; however, the role of presurgical therapy for IVC thrombosis regarding surgical outcomes is not yet clear.

In our study, four patients experienced tumor thrombus level reduction resulting in four patients avoiding a thoracic
Table IV. Adverse events related to presurgical pazopanib.

\begin{tabular}{lcccc}
\hline Adverse event & All grades & $(\%)$ & Grade 3 & $(\%)$ \\
\hline Hyper tension & 4 & $(44)$ & 0 & $(0)$ \\
Hepatic dysfunction & 3 & $(33)$ & 0 & $(0)$ \\
Thrombocytopenia & 2 & $(22)$ & 2 & $(22)$ \\
Hypothyroidism & 2 & $(22)$ & 0 & $(0)$ \\
Hand foot syndrome & 1 & $(11)$ & 1 & $(11)$ \\
Nausea & 1 & $(11)$ & 0 & $(0)$ \\
Fatigue & 1 & $(11)$ & 0 & $(0)$ \\
Stomatitis & 1 & $(11)$ & 0 & $(0)$ \\
Taste disorder & 1 & $(11)$ & 0 & $(0)$ \\
\hline
\end{tabular}

cavity approach and extracorporeal circulation, and three patients avoiding hepatic mobilization. The objective response rate (ORR) was $44 \%$ in our study. The average operative time and blood loss volume in our presurgical group were lower than in the surgery-alone group, even though we failed to reduce the tumor thrombus level in two patients. The different operative times and blood loss volumes can be explained by the fact that any tumor thrombus shrinkage without decreasing the level could improve venous flow in the IVC, which eliminates the fragile collateral venous flow. Surgeons often encounter or must manage collateral veins around renal tumors caused by IVC or renal vein obstruction secondary to the tumor thrombus. Collateral veins increase intraoperative blood loss, and we saw less collateral venous flow in our presurgical group.

Pazopanib is now a first-line treatment for advanced RCC with favorable risk in the major American and European 


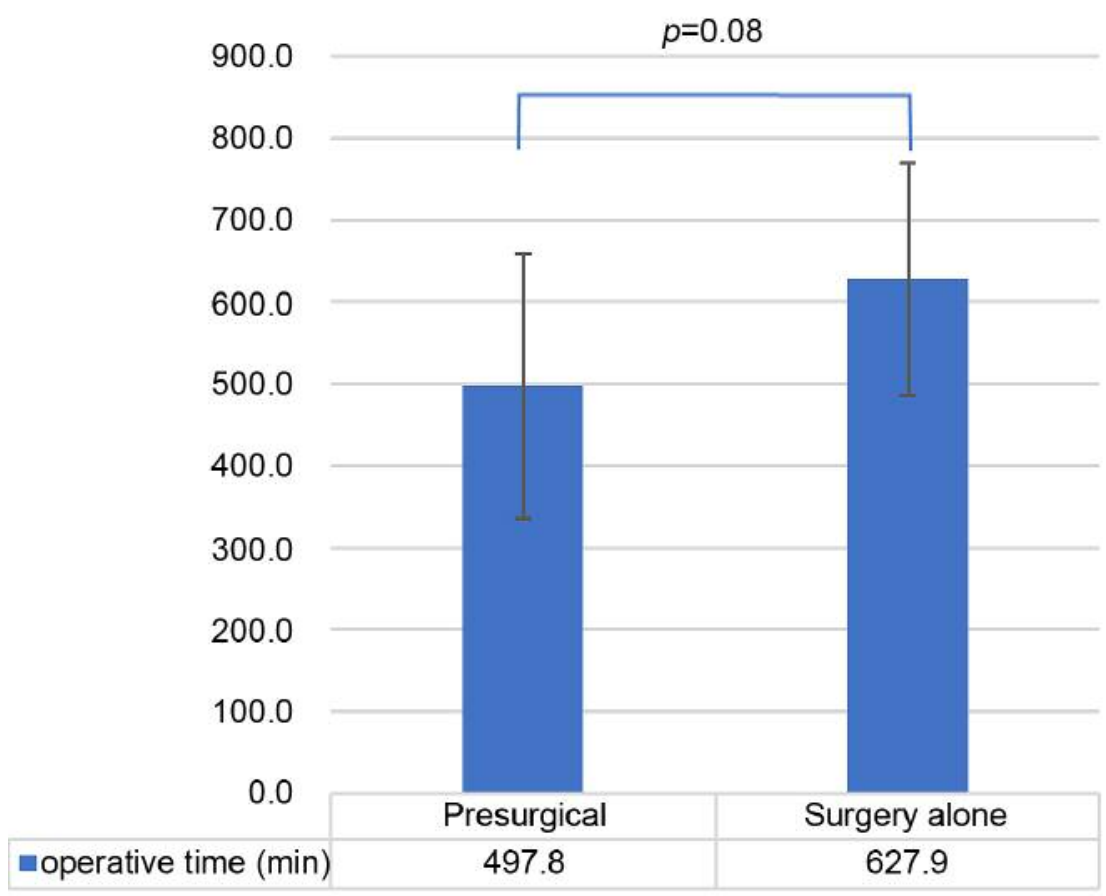

Figure 1. Average operative time in the presurgical group and the surgery-alone group. The error bars show the standard deviation.

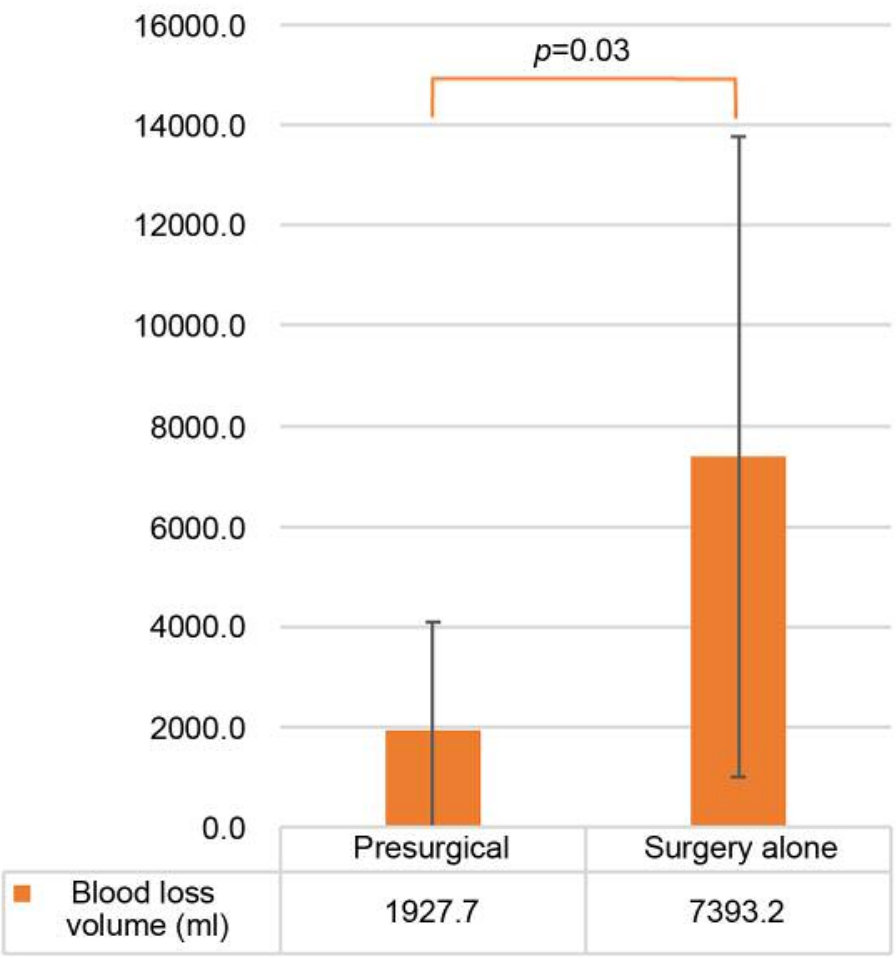

Figure 2. Average blood volume loss. The average blood loss volume was lower in the presurgical group compared to the surgery-alone group. The error bars show the standard deviation. 


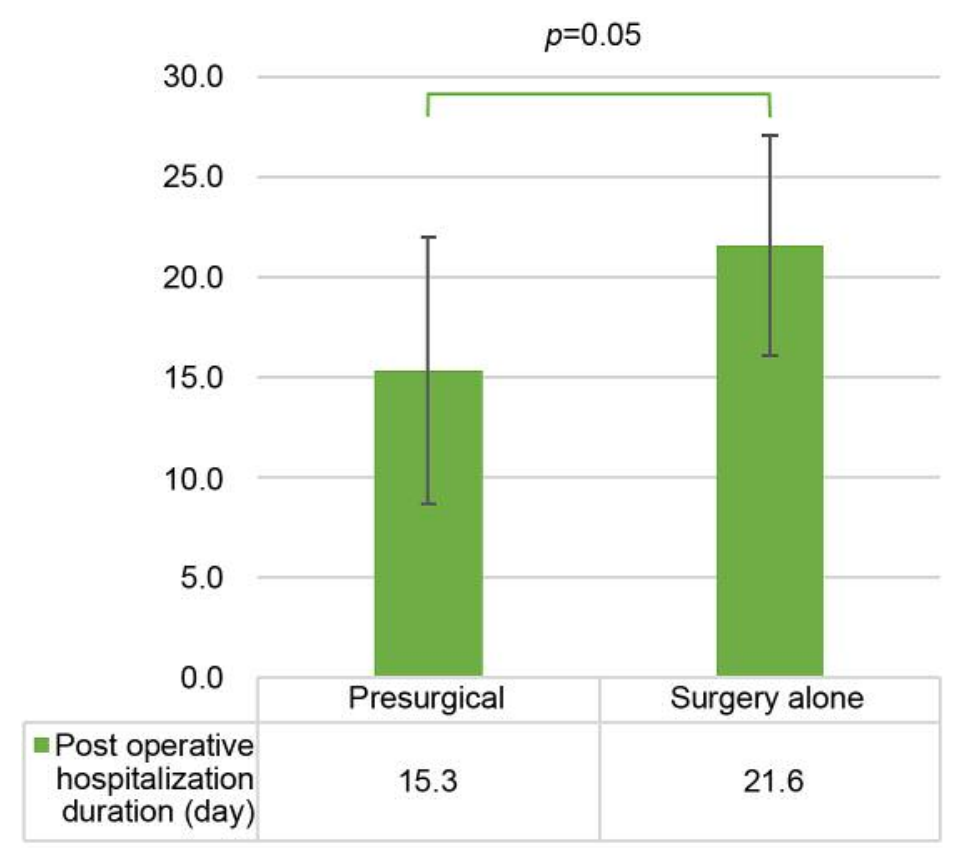

Figure 3. Average postoperative hospitalization duration in the presurgical and surgery-alone groups. The error bars show the standard deviation.

guidelines $(3,4)$. The COMPARZ trial compared the efficacy and safety of pazopanib and sunitinib as first-line therapies; pazopanib was noninferior to sunitinib regarding progression-free survival, and safety and quality of life profiles were better in patients treated with pazopanib (5). In addition, ORR was higher with pazopanib than with sunitinib in the COMPARZ trial ( $31 \%$ vs. $25 \%$, respectively). One major concern with presurgical treatment is the potential to increase perioperative complications. The half-life of pazopanib is shorter than for sunitinib (22-30 h vs. 80-110 h, respectively), and a short half-life can reduce the effect on perioperative complications of presurgical treatment agents. Although immune-checkpoint inhibitors can be used as a presurgical treatment, the ORR in patients treated with immune-checkpoint inhibitors was similar to pazopanib or sunitinib in one study (23), and immune-checkpoint inhibitors have the potential to cause irreversible immunerelated adverse events. Chapin et al. observed an increased complication rate for wound healing and thromboembolism following nephrectomy in patients treated with moleculartargeted agents (24). In our study, the perioperative complication rate was lower in the presurgical group. Chapin et al. used mainly bevacizumab or sunitinib, which may explain the higher complication rate. We consider that our lower perioperative complication rate contributed to the shorter postoperative hospitalization duration in the presurgical group. Adverse events related to presurgical pazopanib treatment occurred in eight patients, and three patients presented with $>$ grade 3 adverse events, in this study. Discontinuation of presurgical treatment because of unacceptable adverse events did not occur; therefore, we consider pazopanib to be suitable for presurgical treatment in RCC patients with IVC tumor thrombosis.

In this study, we could not evaluate a survival benefit of presurgical treatment for RCC with IVC thrombosis because of the short-term observation. The CARMENA trial reported that sunitinib alone was not inferior to presurgical sunitinib in patients with metastatic RCC regarding overall survival and progression-free survival (25). However, in RCC patients with tumor thrombosis without metastasis, it is possible to obtain long-term survival with surgical treatment (2). Our study suggested a potential benefit of presurgical pazopanib for specific patients; however, prospective longterm studies are needed to define the clinical benefits of presurgical treatment in patients with RCC with IVC thrombosis.

This study has several limitations. First, this study had a retrospective design, relatively small number of patients, and short observation period. Second, selection bias and issues regarding missing data were present in this study. Additionally, we could not exclude the influence of improved surgical procedures in our institution on surgical outcomes, namely, lower blood loss volumes, and shorter operative time and hospitalization duration.

In conclusion, for RCC patients with level III or IV IVC tumor thrombosis, presurgical treatment with pazopanib 
decreased the need for surgery and improved surgical outcomes regarding blood loss volume and postoperative hospitalization duration.

\section{Conflicts of Interest}

There are no potential conflicts of interest to disclose regarding this study.

\section{Authors' Contributions}

All Authors contributed to data collection, and participated in writing of the manuscript.

\section{Acknowledgements}

The Authors thank all the patients, their families and investigators who participated in this study.

\section{References}

1 Blute ML, Leibovich BC, Lohse CM, Cheville JC and Zincke $\mathrm{H}$ : The Mayo Clinic experience with surgical management, complications and outcome for patients with renal cell carcinoma and venous tumour thrombus. BJU Int 94: 33-41, 2004. PMID: 15217427. DOI: 10.1111/j.1464-410X. 2004.04897.x

2 Pouliot F, Shuch B, LaRochelle JC, Pantuck A and Belldegrun AS: Contemporary management of renal tumors with venous tumor thrombus. J Urol 184: 833-841, 2010. PMID: 20643450. DOI: $10.1016 /$ j.juro.2010.04.071

3 Terakawa T, Hussein AA, Bando Y, Guru KA, Furukawa J, Shigemura K, Harada K, Hinata N, Nakano Y and Fujisawa M: Presurgical pazopanib for renal cell carcinoma with inferior vena caval thrombus: A single-institution study. Anticancer Drugs 29: 565-571, 2018. PMID: 29629905. DOI: 10.1097/CAD .0000 000000000627

4 Karam JA, Devine CE, Urbauer DL, Lozano M, Maity T, Ahrar K, Tamboli P, Tannir NM and Wood CG: Phase 2 trial of neoadjuvant axitinib in patients with locally advanced nonmetastatic clear cell renal cell carcinoma. Eur Urol 66: 874880, 2014. PMID: 24560330. DOI: 10.1016/j.eururo. 2014.01.035

5 Thomas AA, Rini BI, Lane BR, Garcia J, Dreicer R, Klein EA, Novick AC and Campbell SC: Response of the primary tumor to neoadjuvant sunitinib in patients with advanced renal cell carcinoma. J Urol 181: 518-523, 2009. PMID: 19100579. DOI: 10.1016/j.juro.2008.10.001

6 Rini BI, Garcia J, Elson P, Wood L, Shah S, Stephenson A, Salem M, Gong M, Fergany A, Rabets J, Kaouk J, Krishnamurthi V, Klein E, Dreicer R and Campbell S: The effect of sunitinib on primary renal cell carcinoma and facilitation of subsequent surgery. J Urol 187: 1548-1554, 2012. PMID: 22425095. DOI: $10.1016 /$ j.juro.2011.12.075

7 Hellenthal NJ, Underwood W, Penetrante R, Litwin A, Zhang S, Wilding GE, Teh BT and Kim HL: Prospective clinical trial of preoperative sunitinib in patients with renal cell carcinoma. J Urol 184: 859, 2010. PMID: 20643461. DOI: 10.1016/j.juro.2010.05.041
8 Cowey CL, Amin C, Pruthi RS, Wallen EM, Nielsen ME, Grigson G, Watkins C, Nance K V, Crane J, Jalkut M, Moore DT, Kim WY, Godley PA, Whang YE, Fielding JR and Rathmell WK: Neoadjuvant clinical trial with sorafenib for patients with stage II or higher renal cell carcinoma. J Clin Oncol 28: 1502-1507, 2010. PMID: 20159822. DOI: 10.1200/JCO.2009.24.7759

9 Hatiboglu G, Hohenfellner M, Arslan A, Hadaschik B, Teber D, Radtke JP, Hallscheidt P, Tolstov Y, Roth W, Grüllich C, Huesing J, Duensing $S$ and Pahernik S: Effective downsizing but enhanced intratumoral heterogeneity following neoadjuvant sorafenib in patients with non-metastatic renal cell carcinoma. Langenbeck's Arch Surg 402: 637-644, 2017. PMID: 28012035. DOI: $10.1007 / \mathrm{s} 00423-016-1543-8$

10 Kondo T, Hashimoto Y, Kobayashi H, Iizuka J, Nishikawa T, Nakano $\mathrm{M}$ and Tanabe K: Presurgical targeted therapy with tyrosine kinase inhibitors for advanced renal cell carcinoma: clinical results and histopathological therapeutic effects. Jpn J Clin Oncol 40: 1173-1179, 2010. PMID: 20696817. DOI: $10.1093 /$ jjco/hyq 150

11 Schrader AJ, Steffens S, Schnoeller TJ, Schrader M and Kuczyk MA: Neoadjuvant therapy of renal cell carcinoma: A novel treatment option in the era of targeted therapy? Int J Urol 19: 903-907, 2012. PMID: 22640774. DOI: 10.1111/j.14422042.2012.03065.x

12 Cost NG, Delacroix SE, Sleeper JP, Smith PJ, Youssef RF, Chapin BF, Karam JA, Culp S, Abel EJ, Brugarolas J, Raj GV, Sagalowsky AI, Wood CG and Margulis V: The impact of targeted molecular therapies on the level of renal cell carcinoma vena caval tumor thrombus. Eur Urol 59: 912-918, 2011. PMID: 21367518. DOI: 10.1016/j.eururo.2011.02.032

13 Bigot P, Fardoun T, Bernhard JC, Xylinas E, Berger J, Rouprêt M, Beauval JB, Lagabrielle S, Lebdai S, Ammi M, Baumert H, Escudier B, Grenier N, Hétet JF, Long JA, Paparel P, RiouxLeclercq N, Soulié M, Azzouzi AR, Bensalah K and Patard JJ: Neoadjuvant targeted molecular therapies in patients undergoing nephrectomy and inferior vena cava thrombectomy: is it useful? World J Urol 32: 109-114, 2014. PMID: 23624719. DOI: 10.1007/s00345-013-1088-1

14 Tanaka Y, Hatakeyama S, Hosogoe S, Tanaka T, Hamano I, Kusaka A, Iwamura H, Fujita N, Yamamoto H, Tobisawa Y, Yoneyama T, Yoneyama T, Hashimoto Y, Koie T and Ohyama $\mathrm{C}$ : Presurgical axitinib therapy increases fibrotic reactions within tumor thrombus in renal cell carcinoma with thrombus extending to the inferior vena cava. Int J Clin Oncol 23: 134-141, 2018. PMID: 28752352. DOI: 10.1007/s10147-017-1169-z

15 Horn T, Thalgott MK, Maurer T, Hauner K, Schulz S, Fingerle A, Retz M, Gschwend JE and Kübler HR: Presurgical treatment with sunitinib for renal cell carcinoma with a level III/IV vena cava tumour thrombus. Anticancer Res 32: 1729-1735, 2012. PMID: 22593453.

16 Ljungberg B, Albiges L, Bensalah K, Bex A, Giles R H, Hora M, Kuczyk M A, Lam T, Marconi L, Merseburger A S, Powles T, Staehler M and Volpe A: EAU guidelines on renal cell carcinoma 2018. Available from: http://uroweb.org/guideline/renalcellcarcinoma/(last accessed on 26th March, 2019)

17 National Comprehensive Cancer Network: NCCN clinical practice guidelines in oncology: kidney cancer, 2018. Available from: https://www.nccn.org/professionals/physician_gls/pdf/kidney.pdf (last accessed on 26th March, 2019) 
18 Motzer RJ, Hutson TE, Cella D, Reeves J, Hawkins R, Guo J, Nathan P, Staehler M, de Souza P, Merchan JR, Boleti E, Fife $\mathrm{K}$, Jin J, Jones R, Uemura H, De Giorgi U, Harmenberg U, Wang J, Sternberg CN, Deen K, McCann L, Hackshaw MD, Crescenzo R, Pandite LN and Choueiri TK: Pazopanib versus sunitinib in metastatic renal-cell carcinoma. N Engl J Med 369: 722-731, 2013. PMID: 23964934. DOI: 10.1056/NEJMoa 1303989

19 Grünwald V, Dietrich M and Pond GR: Early tumor shrinkage is independently associated with improved overall survival among patients with metastatic renal cell carcinoma: a validation study using the COMPARZ cohort. World J Urol 36: 1423-1429, 2018. PMID: 29654533. DOI: 10.1007/s00345-018-2297-4

20 Nesbitt JC, Soltero ER, Dinney CP., Walsh GL, Schrump DS, Swanson DA, Pisters LL, Willis, MPH KD and Putnam JB: Surgical management of renal cell carcinoma with inferior vena cava tumor thrombus. Ann Thorac Surg 63: 1592-1600, 1997. PMID: 9205155. DOI: 10.1016/s0003-4975(97)00329-9

21 Terakawa T, Miyake H, Takenaka A, Hara I and Fujisawa M: Clinical outcome of surgical management for patients with renal cell carcinoma involving the inferior vena cava. Int J Urol 14: 781-784, 2007. PMID: 17760741. DOI: 10.1111/j.1442-2042. 2007.01749.x

22 Bindayi A, Hamilton ZA, McDonald ML, Yim K, Millard F, McKay RR, Campbell SC, Rini BI and Derweesh IH: Neoadjuvant therapy for localized and locally advanced renal cell carcinoma. Urol Oncol Semin Orig Investig 36: 31-37, 2018. PMID: 28802883. DOI: 10.1016/j.urolonc.2017.07.015
23 Motzer RJ, Escudier B, McDermott DF, George S, Hammers HJ, Srinivas S, Tykodi SS, Sosman JA, Procopio G, Plimack ER, Castellano D, Choueiri TK, Gurney H, Donskov F, Bono P, Wagstaff J, Gauler TC, Ueda T, Tomita Y, Schutz FA, Kollmannsberger C, Larkin J, Ravaud A, Simon JS, Xu LA, Waxman IM, Sharma P and CheckMate 025 Investigators: Nivolumab versus everolimus in advanced renal-cell carcinoma. N Engl J Med 373: 1803-1813, 2015. PMID: 26406148. DOI: 10.1056/NEJMoa1510665

24 Chapin BF, Delacroix SE, Culp SH, Gonzalez GMN, Tannir NM, Jonasch E, Tamboli P and Wood CG: Safety of presurgical targeted therapy in the setting of metastatic renal cell carcinoma. Eur Urol 60: 964-971, 2011. PMID: 21621907. DOI: 10.1016/j.eururo.2011.05.032

25 Méjean A, Ravaud A, Thezenas S, Colas S, Beauval J-B, Bensalah K, Geoffrois L, Thiery-Vuillemin A, Cormier L, Lang H, Guy L, Gravis G, Rolland F, Linassier C, Lechevallier E, Beisland C, Aitchison M, Oudard S, Patard JJ, Theodore C, Chevreau C, Laguerre B, Hubert J, Gross-Goupil M, Bernhard JC, Albiges L, Timsit MO, Lebret T and Escudier B: Sunitinib alone or after nephrectomy in metastatic renal-cell carcinoma. $\mathrm{N}$ Engl J Med 379: 417-427, 2018. PMID: 29860937. DOI: 10.1056/NEJMoa1803675

Received July 15, 2019

Revised July 23, 2019

Accepted July 24, 2019 